\title{
Adaptive Education based on Learning Styles: Are Learning Style Instruments Precise Enough?
}

\author{
https://doi.org/10.3991/ijet.v13i09.8554 \\ Alzain Meftah Alzain $\left.{ }^{\square}\right)$, Steve Clark, Ali Jwaid \\ Nottingham Trent University, Nottingham, United Kingdom \\ n0214235@ntu.ac.uk \\ Gren Ireson \\ University of Nottingham, Nottingham, United Kingdom
}

\begin{abstract}
Investigating the efficiency of learning style instruments is significant because it is a widespread technique and it enriches the understanding of the challenges of integrating such instruments into adaptive education systems. The results showed that current learning style instruments depend only on the textual form of information to present items; this might be leading to a bias in the measurement of learning styles as the textual forms of information are more suitable for verbal students than for others. The purpose of this paper is to investigate the precision of learning style instruments and the challenges of integrating them into adaptive education systems. This research followed a quantitative research approach. First, a new learning style instrument was developed using different forms of information (Figures, Charts, and Equations). Then, the preferred learning style of fifty students was measured twice, initially, by using the newly developed instrument and subsequently by using a VARK instrument, the results of both were compared.
\end{abstract}

Keywords - adaptive education, learning style, learning style instruments

\section{Introduction}

Research on the use of information technology in computing based education has indicated that students have different abilities and needs. In other words, they tend to learn in different ways. These preferences are called learning styles [1-3]. It is argued that the matching of teaching styles with student preferred learning styles is useful to improve student learning outcomes [1, 4-8]. Many researchers believe that students should know more details about their preferred learning styles because that will help them to be more attracted, engaged and motivated in educational sessions [2, 5, 9-13]. Although a number of learning style instruments were developed over the last few decades, these instruments still have many challenges in terms of efficiency [14]. The question of to what extent learning style instruments are precise is critical for their successful use in adaptive education systems. Previous studies have shown that the current learning style instruments depend heavily on textual forms of information to 
present items, and this property may make it more appropriate and attractive for verbal types of learners. Consequently, this might be leading to a bias for verbal learners, more than others, such as visual and active learners [15].

The main aim of this study is to investigate the impact of using different forms of information (visual and active) for building learning style instruments, and the impact of that on the accuracy of measurement. To reach this, the following research hypothesis is proposed:

H0: constructing learning style instruments using different forms of information (visual and active content) will not impact the measuring of learning preferences.

H1: constructing learning style instruments using different forms of information (visual and active content) will impact the measuring of learning preferences.

Although learning styles were defined more than half a century ago, and a number of studies have been conducted during this period, there are relatively few studies focusing on the type of content, which could be used to build the learning style instruments. In 2017, Alzain studied qualitatively, the possible impact of content type on the accuracy of learning style instruments [15]. This study complements the existing research in this topic. This research is significant because it enriches the understanding of the challenges involved in designing and developing such instruments. This research can also contribute to improve the understanding of the challenges of integrating these instruments into adaptive education systems.

The following sections of the paper will address, the literature, research methodology, data collected, results and discussion and finally areas of further research.

\section{Literature review}

As a research area, investigating the ways in which student learning varies has attracted the interest of researchers due to the need to improve education systems so this can better cater for all students. This section reviews the main concepts related to the research field from the following three aspects: the learning style instruments, adaptive education systems, and how instruments were integrated into the adaptive education systems.

\subsection{Learning style}

The concept of style in the learning process indicates the fact that students differ as to how they receive new information and how they interact with that information [16]. Therefore, students who have visual preferences tend to obtain more knowledge from the materials that depend on the visual forms of information, whereas the same material will be more useful for the learners with verbal preferences if these materials are represented using text and audio. Moreover, some students tend to learn more through 'doing', whereas some others prefer to 'think and reflect'. These preferences are called learning styles [1-3]. Over the last few decades, a number of learning style models and instruments were developed. In this research, five well-known models [17] are investigated for comparison purposes. See Table 1 
Table 1. Differences and similarities of learning styles.

\begin{tabular}{|c|c|c|c|c|c|}
\hline Model & Definition of Learning Style & $\begin{array}{l}\text { Number of } \\
\text { dimensions }\end{array}$ & Instrument & Content & $\begin{array}{l}\text { Instrument } \\
\text { mechanism }\end{array}$ \\
\hline $\begin{array}{l}\text { Felder- } \\
\text { Silverman }\end{array}$ & $\begin{array}{l}\text { "The characteristic strengths and } \\
\text { preferences in the ways individuals } \\
\text { take in and process information" } \\
{[17]}\end{array}$ & 5 & $\begin{array}{l}\text { Index of Learn- } \\
\text { ing Style (ISL) }\end{array}$ & Text only & $\begin{array}{l}\text { Select only } \\
\text { one answer } \\
\text { from two } \\
\text { alternatives }\end{array}$ \\
\hline VARK & $\begin{array}{l}\text { “An individual's characteristics and } \\
\text { preferred ways of gathering, organ- } \\
\text { izing, and thinking about infor- } \\
\text { mation" [17] }\end{array}$ & 2 & $\begin{array}{l}\text { VARK Ques- } \\
\text { tionnaire }\end{array}$ & Text only & $\begin{array}{l}\text { Select one or } \\
\text { more answer } \\
\text { from the four } \\
\text { alternatives }\end{array}$ \\
\hline Kolb & $\begin{array}{l}\text { "Generalized differences in learning } \\
\text { orientation based on the degree to } \\
\text { which people emphasize the four } \\
\text { modes of the learning process" }[18]\end{array}$ & 2 & $\begin{array}{l}\text { Learning Style } \\
\text { Inventory (LSI) }\end{array}$ & Text only & $\begin{array}{l}\text { Rank-order } \\
\text { set of items }\end{array}$ \\
\hline Dunn-Dunn & $\begin{array}{l}\text { "The way in which individuals } \\
\text { begin to concentrate on, process, } \\
\text { internalize, and retain new and } \\
\text { difficult information" [19] }\end{array}$ & 5 & $\begin{array}{l}\text { Productivity } \\
\text { Environmental } \\
\text { Preference } \\
\text { Survey (PEPS) } \\
\end{array}$ & Text only & $\begin{array}{l}\text { Likert-type } \\
\text { scale }\end{array}$ \\
\hline Gregorc & $\begin{array}{l}\text { "Distinctive and observable } \\
\text { behaviours that provide clues about } \\
\text { the mediation abilities of individuals } \\
\text { and how their minds relate to the } \\
\text { world and, therefore, how they } \\
\text { learn" [20] }\end{array}$ & 4 & $\begin{array}{l}\text { Gregorc Style } \\
\text { Delineator } \\
\text { (GSD) }\end{array}$ & Text only & $\begin{array}{l}\text { Rank-order } \\
\text { set of items }\end{array}$ \\
\hline
\end{tabular}

Based on the previous investigations, it is necessary for a number of important points to be noted:

1. Content of existing instruments:

(a) All of the existing learning style instruments were built using only the textual form of information, which is considered more suitable for verbal learners than others [15]. Consequently, these instruments might be more suitable and motivating for the verbal type of students than others.

2. Instruments Mechanism: each instrument consist of a set of items, each of which has a number of answers (alternatives) and the participant needs to select the best answer(s):

(a) In the instruments that depend on selecting only one answer from a set of alternatives: This mechanism seems to be inconsistent with the argument that learning styles are not dichotomies (either/or) options, because learners could have aspects of say visual and verbal learning at the same time.

(b) In the instruments that depend on selecting more than one answer from a set of alternatives that correspond to different learning styles: this mechanism could not be fully accurate, because the selected answers have the same weight of significance statistically, while learners could fall under both poles (say visual and verbal) of one dimension but with varying level of preference (pure, moderate and mild). 
(c) In the instruments that depend on ranking set of alternatives: ranking a set of answers without the possibility of giving the same level of importance for more than one answer at the same time could be a restrictive mechanism.

\subsection{Adaptive education systems}

Although students have different preferences, goals, experience and knowledge, traditional educational systems provide the same static content for all student [21]. Therefore, in considering the individual differences between students, adaptive systems have been harnessed in the education field. Adaptive educational systems have been defined as "technological component of joint human-machine systems that can change their behavior to meet the changing needs of their users, often without explicit instructions from their users" [22]. This generation of education systems can provide the student with materials that are adapted especially to preferences, goals, experiences or knowledge of the subject [21, 23, 24].

\subsection{Incorporating learning style into adaptive education systems}

An adaptive education system aims to take into account the individual differences among students by providing the materials, activities and teaching methods that best accommodate student needs and abilities. However, we also need to know: what student features can be used for achieving the adaptation process, "adaptation to what?" [2]. In recent work, Özyurt [25] within the scope of adaptive education systems, 69 studies published from 2005 to 2014 were analysed. This demonstrated that the learning style is one of the most common and important parameters that could be used when designing adaptive learning environments, to consider the individual differences among students. The results of this study reveal that: forty-eight studies out of sixtynine (69.6 per cent) depend on learning style instruments to determine student learning preferences in order to achieve the adaptation process, whilst remainder (twentyone studies, $30.4 \%$ ) used different techniques and methods such as artificial intelligence methods and classification algorithms. With reference to learning styles models and instruments that have been employed in these studies, the results show that, the Felder-Silverman learning style model was the most preferred model (42\%), followed by the Kolb model (14.5\%). More recently, Truong investigated integrating learning styles in adaptive e-learning systems by reviewing 51 studies published from (2004 to 2014), the results of this study show that, the Felder-Silverman learning style model was the most preferred model (70.6\%), and then the VARK model (9.8\%) [12]. A number of previous adaptive systems that depend on learning style instruments were investigated for comparison purposes. See Table 2. 
Table 2. Summary of previous adaptive education systems

\begin{tabular}{|c|c|c|c|}
\hline System & Instrument & Preferences & Evaluation \\
\hline CS383 & $\begin{array}{l}\text { index of learning style } \\
\text { instrument }\end{array}$ & $\begin{array}{l}\text { sensing-intuitive, visual- } \\
\text { verbal and sequential-global } \\
\text { dimension }\end{array}$ & $\begin{array}{l}\text { No formal experimental re- } \\
\text { search has been conducted to } \\
\text { evaluate it (informal assess- } \\
\text { ment) [26] }\end{array}$ \\
\hline INSPIRE & $\begin{array}{l}\text { Honey and Mumford } \\
\text { questionnaire. } \\
\text { (Student profile can be } \\
\text { updated manually ) }\end{array}$ & Reflector-activist & $\begin{array}{l}\text { An empirical study with twen- } \\
\text { ty-three participants was con- } \\
\text { ducted [27] }\end{array}$ \\
\hline Arthur & $\begin{array}{l}\text { Determine by the system } \\
\text { (No psychometric instru- } \\
\text { ment ) }\end{array}$ & $\begin{array}{l}\text { visual-interactive, auditory- } \\
\text { text, auditory-lecture, text- } \\
\text { only presentation }\end{array}$ & $\begin{array}{l}\text { An empirical study with } 89 \\
\text { participants was conducted [27] }\end{array}$ \\
\hline EDUEC & $\begin{array}{l}\text { MIDAS Multiple intelli- } \\
\text { gence inventory }\end{array}$ & $\begin{array}{l}\text { logical/mathematical, ver- } \\
\text { bal/linguistic, visual/spatial } \\
\text { and musical/rhythmic }\end{array}$ & $\begin{array}{l}\text { two empirical studies with (117 } \\
\text { participants) were conducted } \\
{[26,28]}\end{array}$ \\
\hline ILASH & $\begin{array}{l}\text { Index of learning style } \\
\text { questionnaire (ILS) }\end{array}$ & global/sequential dimension & $\begin{array}{l}\text { An empirical study with twen- } \\
\text { ty-two participants was con- } \\
\text { ducted }[29,30]\end{array}$ \\
\hline $3 \mathrm{DE}$ & $\begin{array}{l}\text { Honey and Mumford } \\
\text { questionnaire (students has } \\
\text { privileges to decide wheth- } \\
\text { er follow his/her preferred } \\
\text { learning style or try an } \\
\text { another alternative) }\end{array}$ & Activists, Reflectors & $\begin{array}{l}\text { A cross-cultural empirical study } \\
\text { was conducted and } 40 \text { partici- } \\
\text { pants from each country (Italy, } \\
\text { France, Spain, Finland) have } \\
\text { participated }[31,32]\end{array}$ \\
\hline iWeaver & $\begin{array}{l}\text { Building Excellence Inven- } \\
\text { tory }\end{array}$ & $\begin{array}{l}\text { Global, analytical, impulsive, } \\
\text { reflective, } \\
\text { visual, auditory, kinaesthetic }\end{array}$ & $\begin{array}{l}\text { A workshop with sixty-three } \\
\text { learners was conducted }[26,33]\end{array}$ \\
\hline AHA! & $\begin{array}{l}\text { LAG-XLS generic adaptive } \\
\text { language. Students update } \\
\text { change his/her profile using } \\
\text { special forms. }\end{array}$ & $\begin{array}{l}\text { Providing pre-defined strate- } \\
\text { gies for (Active-Reflective, } \\
\text { Verbalizer-Imager, Global- } \\
\text { Analytic and Field Depend- } \\
\text { ent-Field Independent), } \\
\text { authors can build their own } \\
\text { strategy }\end{array}$ & $\begin{array}{l}\text { An empirical study with thirty- } \\
\text { four participants was conducted } \\
{[24,34,35]}\end{array}$ \\
\hline TANGOW & $\begin{array}{l}\text { Index of learning style } \\
\text { questionnaire (ILS) and } \\
\text { updating the student pro- } \\
\text { files using student actions, } \\
\text { background, age and } \\
\text { language. }\end{array}$ & $\begin{array}{l}\text { sensing-intuitive and sequen- } \\
\text { tial-global }\end{array}$ & $\begin{array}{l}\text { No formal experimental re- } \\
\text { search has been conducted to } \\
\text { evaluate this system }[36-38]\end{array}$ \\
\hline
\end{tabular}

\section{$3 \quad$ Research method}

This section highlights the research methods harnessed for this study.

\subsection{Adaptive education systems}

The main aim of this research is to investigate the effect of using different forms of information (visual and active) in constructing learning style instruments, and how 
this will effect the efficiency and effectiveness of these instruments. This investigation was conducted in the School of Science and Technology at Nottingham Trent University, and the data was collected from 50 students: of the 50 students who agreed to engage, 10 were female and 40 male. Only 6 participants were studying at postgraduate level and the other 44 students were undergraduates.

Before starting the experiment, the researcher provided the participants with a brief idea about the research and discussed with them some related issues such as:

1. The concept and theory of learning styles;

2. Dimensions of learning styles;

3. The previous learning style models and instruments.

The preferred learning style of participants was then measured twice. Initially, by using the newly developed instrument and subsequently by using a VARK instrument. The results of both were compared and data was analysed using SPSS Version 22. A paired t-test was conducted to determine if there were any significant differences between student learning styles measured by the two instruments.

\subsection{Methods of data collection}

On the first iteration, the preferred learning style of the participants was measured using the ALSI instrument. This instrument was developed using different forms of information such as (Figures, Charts, and Equations) [15]. Figure 1 shows a sample of the ALSI instrument.

Secondly, the preferred learning styles of participants were measured using the VARK questionnaire, which is constructed using text only. Figure 2 show a sample of the VARK questionnaire.

Both instruments consist of 16 questions, each of which has four responses, and the participants needs to select the answer(s) that best fits their preference (they are allowed to choose more than one answer). 
Q14: Which way do you prefer to explain the method of mean calculation?
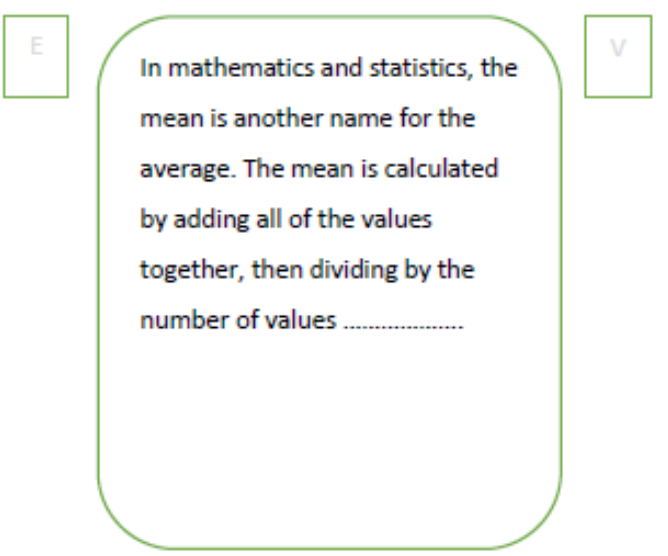

Mean $=$ sum of values $\div$ number of values

$\frac{X_{1}+X_{2}+X_{3}+\ldots+X_{N}}{N}$ Mean
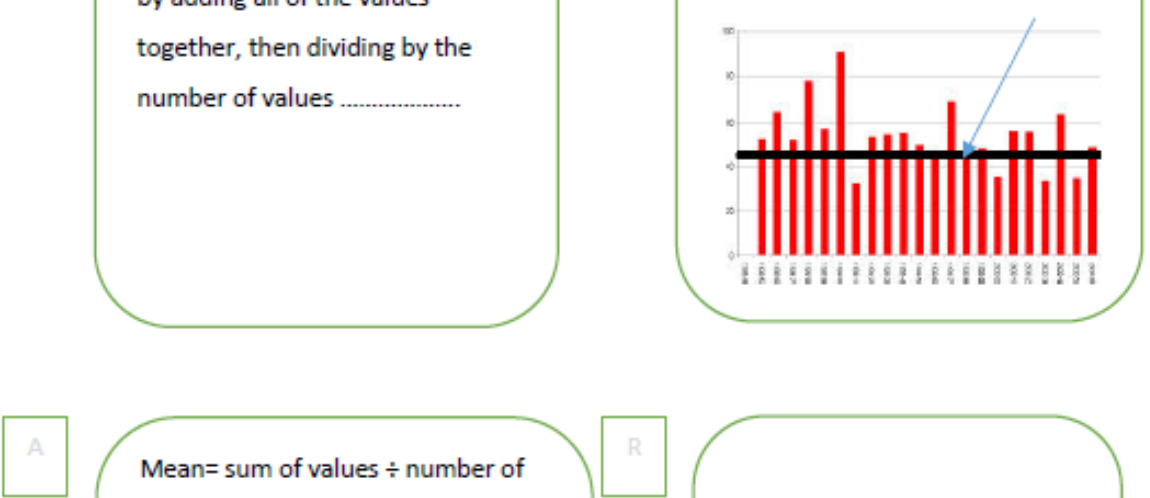

$$
\begin{aligned}
& \text { Mean }=\text { sum of values } \div \text { number of } \\
& \text { values } \\
& \qquad M=\frac{X 1+X 2+X 3+\cdots+X N}{N}
\end{aligned}
$$

Ex: Mean of $(10,2,7,1)=20 \div 4$

Q: Mean of $(11,5,7,3,4)=\ldots \ldots$.

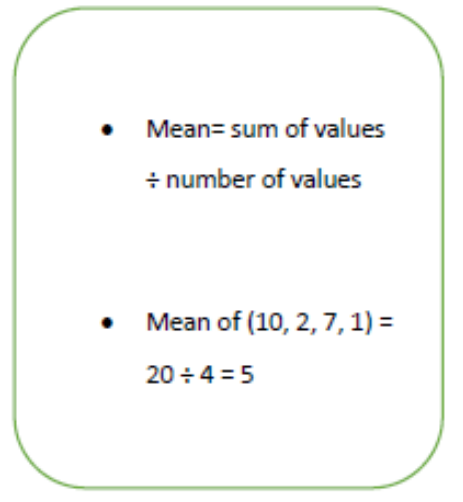

Fig. 1. ALSI instrument sample.

Do you prefer a teacher or a presenter who uses:

demonstrations, models or practical sessions.

$\square$ question and answer, talk, group discussion, or guest speakers.

$\square$ diagrams, charts or graphs.

$\square$ handouts, books, or readings.

Fig. 2. VARK questionnaire sample. 


\section{$4 \quad$ Results}

The preferred learning styles of participants were measured using both instruments. Table 3 illustrates the distribution of participant preferences based on the ALSI instrument and the VARK questionnaire. For visual impact, this data is displayed in figure 3 .

Table 3. Participants distribution based on learning styles using the VARK instrument and the ALSI instrument.

\begin{tabular}{|l|c|c|c|c|c|c|c|c|}
\hline \multirow{2}{*}{ Score } & \multicolumn{2}{|c|}{ Visual } & \multicolumn{2}{c|}{ Verbal } & \multicolumn{2}{c|}{ Active } & \multicolumn{2}{c|}{ Passive } \\
\cline { 2 - 9 } & $\boldsymbol{A L S I}$ & $\boldsymbol{V A R K}$ & $\boldsymbol{A L S I}$ & $\boldsymbol{V A R K}$ & $\boldsymbol{A L S I}$ & $\boldsymbol{V A R K}$ & $\boldsymbol{A L S I}$ & $\boldsymbol{V A R K}$ \\
\hline Pure & 24 & 1 & 4 & 1 & 25 & 7 & 2 & 1 \\
\hline Moderate & 25 & 17 & 33 & 20 & 25 & 28 & 32 & 13 \\
\hline Mild & 1 & 32 & 13 & 29 & 0 & 15 & 16 & 36 \\
\hline
\end{tabular}

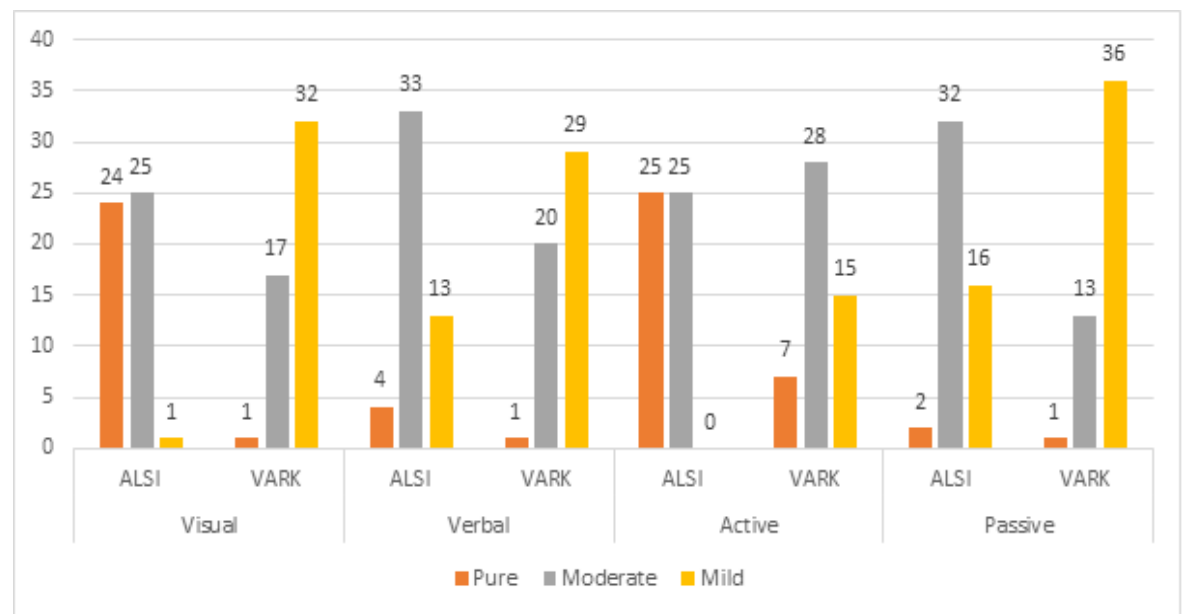

Fig. 3. Visual presentation of participant distribution based on learning styles.

With reference to the research hypothesis, "constructing the instruments of learning style using the different forms of information (visual and active content) will not impact the measuring of learning preferences?". A paired t-test was conducted to determine if there were any significant differences between the mean student learning styles scores.

Based on the results of the Paired t-test, there were significant differences among students preferred learning styles, whereby the value of $(p)$ in each dimension is less than 0.5 :

1. Visual style $(\mathrm{t}=-12.94, \mathrm{p}=0.000)$.

2. Verbal style $(\mathrm{t}=-3.87, \mathrm{p}=0.000)$.

3. Active style $(\mathrm{t}=-9.91, \mathrm{p}=0.000)$.

4. Passive style $(\mathrm{t}=-6.03, \mathrm{p}=0.000)$. 
These results confirm the alternative hypothesis ( $\mathrm{H} 0)$, and prove that using different forms of information (visual and active content) to construct learning style instruments will significantly impact the measuring of learning preferences.

The effect size was also measured for each individual scale. The results of Cohen's $d$ revealed that the highest effect size $(d=2.37)$ was in the visual scale followed by the active scale $(d=1.72)$ and then the passive scale $(d=1.15)$, and the lowest effect size $(d=0.71)$ was in the verbal scale.

\section{Discussion}

This research investigated empirically the effect of using different forms of information such as visual and active content to constructing learning style instruments, and the impact of that on the efficiency and accuracy of these instruments. Generally, the results showed that using visual and active content in the instrument construction has a considerable influence on the measurement of learning styles. The results showed that the number of students whose learning style was characterized as "visual" increased significantly when they used the ALSI instrument, which was built using visual and active content. This result aligns with a concept of learning style theory, which states that the visual type of learner responds strongly to visual forms of information (figures, charts, pictures... etc.). The results also showed an increase in the number of students whose learning style was characterized as "active" when they used the ALSI instrument, that contained active content. In contrast, the "verbal" and "passive" preferences have not seen as big a difference as the "visual" and "active" types. This may be interpreted by the fact that the textual content was extensively used in the construction of previous instruments.

Although, these results have emerged from quantitative experiments they are supported by the qualitative research conducted in 2016 [15]. However, there is a need for more investigation in terms of the impact of instrument content types on the accuracy of measuring learning styles. Since we know that these instruments have used by most adaptive educational systems for the purpose of matching the teaching style with student preferred learning styles [25]. Accordingly, before we build our teaching approach based on learning style instruments, it is important to investigate to what extent these instruments measure what we think is being measured.

An important implication of these findings is that the possibility of changing the learning preferences according to the content of the instrument that is used to measure theses preferences. Therefore, although matching the teaching strategies with student preferred learning styles has been found to have a positive impact on student performance, it seems to be critical to build our teaching systems in light of the consequences of the instrument, especially if the instrument itself does not fully reflect reality. 


\section{Conclusion}

The findings of this study indicated that the scores of measuring the preferred learning styles of the participants varied according to the approach in the questions presented in the learning style instrument. In this case, the researcher argues that items of the instruments ought to be presented in a manner which corresponds to different learning styles, in light of the fact that the learners will respond strongly to patterns of information which correspond to their preferred style. Consequently, this will provide some solutions for the problems that might arise from using only textual information to construct learning style instruments.

\section{$7 \quad$ References}

[1] A. L. Franzoni, S. Assar, B. Defude and J. Rojas, "Student learning styles adaptation method based on teaching strategies and electronic media," in Advanced Learning Technologies, 2008. ICALT'08. Eighth IEEE International Conference On, 2008, pp. 778-782.

[2] M. T. Alshammari, "Adaptation Based On Learning Style And Knowledge Level In ELearning Systems, Ph.D thesis," 2016.

[3] A. M. Alzain, S. Clark, G. Ireson and A. Jwaid, "A study of the reliability and validity of the first arabic learning styles instrument (ALSI)," in Sustainable Technologies (WCST), 2016 World Congress On, 2016, pp. 29-34.

[4] A. M. Alzain, S. Clark and G. Ireson, "Libyan higher education system, challenges and achievements," in Engineering Education (ICEED), 2014 IEEE 6th Conference On, 2014, pp. 67-72.

[5] R. M. Felder and J. Spurlin, "Applications, reliability and validity of the index of learning styles," International Journal of Engineering Education, vol. 21, pp. 103-112, 2005.

[6] A. Franzoni-Velázquez, F. Cervantes-Pérez and S. Assar, "A Quantitative Analysis of Student Learning Styles and Teacher Teachings Strategies in a Mexican Higher Education Institution," Journal of Applied Research and Technology, vol. 10, pp. 289-308, 2012.

[7] L. M. Miller, "Using learning styles to evaluate computer-based instruction," Comput. Hum. Behav., vol. 21, pp. 287-306, 2005. https://doi.org/10.1016/j.chb.2004.02.011

[8] L. Thomas, M. Ratcliffe, J. Woodbury and E. Jarman, "Learning styles and performance in the introductory programming sequence," in ACM SIGCSE Bulletin, 2002, pp. 33-37. https://doi.org/10.1145/563517.563352

[9] Z. A. Akasah and M. Alias, "Emphasizing learning of the affective domain for the realization of the engineering learning outcomes," Cognition, vol. 7, pp. 9, 2010.

[10] N. Fleming and D. Baume, "Learning Styles Again: VARKing up the right tree!" Educational Developments, vol. 7, pp. 4, 2006.

[11] N. Othman and M. H. Amiruddin, "Different perspectives of learning styles from VARK model," Procedia-Social and Behavioral Sciences, vol. 7, pp. 652-660, 2010. https://doi.org/10.1016/j.sbspro.2010.10.088

[12] H. M. Truong, "Integrating learning styles and adaptive e-learning system: current developments, problems and opportunities," Comput. Hum. Behav., vol. 55, pp. 1185-1193, 2016. https://doi.org/10.1016/j.chb.2015.02.014

[13] L. Herod, "Learning Styles \& Strategies," Adult Learning \& Literacy, pp. 310-800, 2004.

[14] P. A. Kirschner, "Stop propagating the learning styles myth," Comput. Educ., vol. 106, pp. 166-171, 2017. https://doi.org/10.1016/j.compedu.2016.12.006 
[15] A. M. Alzain, G. Ireson, S. Clark and A. Jwaid, "Learning style instruments and impact of content: A qualitative study," in Sustainable Technologies (WCST), 2016 World Congress On, 2016, pp. 109-114.

[16] T. J. Sewall, "The measurement of learning style: A critique of four assessment tools." ERIC, Tech. Rep. ED267247, 1986.

[17] T. F. Hawk and A. J. Shah, "Using learning style instruments to enhance student learning," Decision Sciences Journal of Innovative Education, vol. 5, pp. 1-19, 2007. https://doi.org/10.1111/j.1540-4609.2007.00125.x

[18] D. A. Kolb, Experiential Learning: Experience as the Source of Learning and Development. FT Press, 2014.

[19] R. Dunn, "Understanding the Dunn and Dunn learning styles model and the need for individual diagnosis and prescription," Reading, Writing, and Learning Disabilities, vol. 6, pp. 223-247, 1990. https://doi.org/10.1080/0748763900060303

[20] A. F. Gregorc, "Learning/teaching styles: Their nature and effects," Student Learning Styles: Diagnosing and Prescribing Programs, pp. 19-26, 1979.

[21] P. Brusilovsky, "Adaptive hypermedia. User Modeling and User Adapted Interaction," Ten Year Anniversary Issue (Alfred Kobsa, Ed.), vol. 11, pp. 87 - 110, 2001.

[22] K. M. Feigh, M. C. Dorneich and C. C. Hayes, "Toward a characterization of adaptive systems: a framework for researchers and system designers," Hum. Factors, vol. 54, pp. 10081024, Dec, 2012. https://doi.org/10.1177/0018720812443983

[23] P. Brusilovsky, "Methods and techniques of adaptive hypermedia," in Adaptive Hypertext and HypermediaAnonymous Springer, 1998, pp. 1-43.

[24] N. Stash, "Incorporating cognitive/learning styles in a general-purpose adaptive hypermedia system," Dissertation Abstracts International, vol. 68, 2007.

[25] Ö Özyurt and H. Özyurt, "Learning style based individualized adaptive e-learning environments: Content analysis of the articles published from 2005 to 2014," Comput. Hum. Behav., vol. 52, pp. 349-358, 2015. https://doi.org/10.1016/j.chb.2015.06.020

[26] N. Al-Jojo, "Teacher assisting and subject adaptive material system: an Arabic adaptive learning environment, Ph.D. thesis," Teacher Assisting and Subject Adaptive Material System: An Arabic Adaptive Learning Environment, 2012.

[27] A. A. Alghamdi, "An adaptive educational system that caters for combination of two models of learning styles, Ph.D. thesis," An Adaptive Educational System that Caters for Combination of Two Models of Learning Styles, PhD Thesis, 2010.

[28] D. Kelly and B. Tangney, "Matching and mismatching learning characteristics with multiple intelligence based content." in Aied, 2005, pp. 354-361.

[29] N. Bajraktarevic, W. Hall and P. Fullick, "ILASH: Incorporating learning strategies in hypermedia," in In Proceedings of the Workshop on Adaptive Hypermedia and Adaptive Web-Based Systems (no. 1999, Pp. 41-52). 2003, .

[30] N. Bajraktarevic, W. Hall and P. Fullick, "Incorporating learning styles in hypermedia environment: Empirical evaluation," in Proceedings of the Workshop on Adaptive Hypermedia and Adaptive Web-Based Systems, 2003, pp. 41-52.

[31] D. Corso, E. Ovcin, G. Morrone, D. Gianesini, S. Salojarvi and T. Kvist, "3DE: An environment for the development of learner-centered custom educational packages," in Frontiers in Education Conference, 2001. 31st Annual, 2001, pp. F2C-21-6 vol. 2.

[32] D. D. Corso, E. Ovcin, G. Morrone and D. Gianesin, "The 3DE custom course compiler: An engine to assemble custom web courses," in Frontiers in Education, 2002. FIE 2002. 32nd Annual, 2002, pp. F2E-2-F2E-7 vol. 2. 
[33] C. Wolf, "iWeaver: Towards' learning style'-based e-learning in computer science education," in Proceedings of the Fifth Australasian Conference on Computing EducationVolume 20, 2003, pp. 273-279.

[34] N. V. Stash, A. I. Cristea and P. M. De Bra, "Authoring of learning styles in adaptive hypermedia: Problems and solutions," in Proceedings of the 13th International World Wide Web Conference on Alternate Track Papers \& Posters, 2004, pp. 114-123. https://doi.org/10.1145/1013367.1013387

[35] N. Stash, A. I. Cristea and P. De Bra, "Adaptation to learning styles in e-learning: Approach evaluation," in In E-Learn: World Conference on E-Learning in Corporate, Government, Healthcare, and Higher Education(Pp. 284-291). 2006, .

[36] P. Paredes and P. Rodriguez, "A mixed approach to modelling learning styles in adaptive educational hypermedia," Advanced Technology for Learning, vol. 1, pp. 210-215, 2004. https://doi.org/10.2316/Journal.208.2004.4.208-0823

[37] M. R. Zakaria, "The hybrid model, and adaptive educational hypermedia frameworks, Ph.D. thesis," The Hybrid Model, and Adaptive Educational Hypermedia Frameworks, 2004.

[38] E. Brown, "The use of Learning Styles in Adaptive Hypermedia, Ph.D. thesis," The use of Learning Styles in Adaptive Hypermedia, 2007.

\section{Authors}

Alzain Alzain is an academic researcher in the School of Science and Technology at Nottingham Trent University. He is a senior lecturer in Misurata University at the Faculty of Education. His published research focuses learning in computer science, especially individual differences. He collaborates with colleagues in Education and Science.

Dr. Steve Clark is an academic researcher in the School of Science and Technology and has published in several areas of Engineering and Computing and the Pedagogy for these subjects. He collaborates with colleagues in Education and Science.

Dr. Gren Ireson is an academic researcher at University of Nottingham. His published research focuses learning in physical science, especially quantum phenomena and superconductivity, women in STEM subjects and the physics of sport. He collaborates with colleagues in computer science, biomedical sciences and the built environment.

Dr. Ali Jwaid is an academic researcher and lecturer in the School of Science and Technology at Nottingham Trent University and has published in Engineering and the Pedagogy. He collaborates with colleagues to improve teaching and learning in the university Education and Science.

Article submitted 09 March 2018. Resubmitted 02 April 2018. Final acceptance 24 April 2018. Final version published as submitted by the authors. 